\title{
The Mark of the Phallus: Homoerotic Desire in Borges' "La forma de la espada"
}

\author{
Herbert J. Brant \\ Indiana University-Purdue University Indianapolis \\ [Published in Chasqui 25.1 (May 1996): 25-38.]
}

\author{
"Envidia. \\ Envidia siente el cobarde... \\ Envidia. \\ Envidia amarga y traidora, \\ Envidia que grita y llora. \\ La que causa más dolor \\ es la envidia por amor." \\ José González Castillo, \\ "Envidia"
}

The fiction of Jorge Luis Borges is intriguing and yet, unsettling. These qualities seem to originate in what I consider two principal characteristics of Borges' work: confounding ambivalence and a clever use of paradox. His work is paradoxical insofar as it is macrocosmic, and yet microcosmic; central, and yet peripheral; collective- - it seems to speak with many voices - and yet it is deeply personal and evokes the strongest emotional responses, especially in lyrical passages that reveal the unmistakable presence of Borges himself. It is precise, concise, and straightforward in its expression, and yet there is something ambiguous, nebulous, and absent in its style. These and other contradictory qualities amplify the richness and suggestivity of Borges' stories and may help explain the extraordinary quantity of criticism devoted to them. 
Paradox in Borges' work is frequently indicated by a mask used to disugise a false identity. As critics such as Emir Rodríguez Monegal (29-32) and Sylvia Molloy (18-25) have noted, Borges' fascination (and discomfort) for masks, a life-long obsession with paradoxical dualities in which truth is concealed by false appearance, becomes a central organizing principle in Borges' writings. The craft of fiction for Borges, then, is the unmasking of the reality lying below the surface of the false façade. And this process of revelation is accompanied by the simultaneous sensations of pleasure and uneasiness. In this essay, I will examine how Borges cleverly uses a visible mark as a mask, concealing as well as displaying the truth regarding the main character in the story, "La forma de la espada." The reality that the Borgesian mask both disguises (closets) and reveals (outs) is homoerotic desire.

There is no doubt, in my opinion, that there is something fundamentally queer ${ }^{1}$ about Borges' writing. The literary universe that Borges has projected is an essentially homosocial space, populated almost exclusively by men who love each other, hate each other, betray each other, ${ }^{2}$ sacrifice for each other; it is a world where no man successfully relates either socially or sexually to any woman; it is also a place where men interact passionately with other men through art and culture, intellectual games, battles and duels. It is, in other words, an imagined location in which men form deep, intimate bonds and relationships with other men in the almost total absence of women. The extent of the homosocial nature of Borges' world becomes immediately apparent when the reader discovers that there are central female characters in only nine stories by Borges (Agheana 381) and that most of them are closely related to themes of "death, violence and often sacrifice" (Magnarelli 142).

A close look at Borges' fictional world reveals relationships between men indicating more than a bond of friendship or a meeting of minds, more than a fusion of identities. In story after story, Borges has made a practice of replacing the traditional image of the union of opposites represented in sexual terms (female and male) by substituting the gender opposites (feminine and 
masculine) existing within each individual man. Borges does not follow the social and literary custom of men seeking delight and fulfillment in the "opposite sex." Instead, men in the Borgesian universe must join with other men to find wholeness, peace and symmetry. As a result, in Borges' stories the act of union or fusion of two men, physically, spiritually and emotionally manifests graphically the now infamous Borgesian obsession with completeness, totality, and harmony as a release or escape from the tyranny of chaos and fragmentation.

For some critics, it may be a bold or even a shocking project to link the work of such an important canonical writer as Jorge Luis Borges with a gay theme. In their insightful studies on Borges, both Daniel Altamiranda and Daniel Balderston ("Fecal") note that Borges himself found the topic of homosexuality extremely troubling and made strongly negative public statements about it. One frightful example can be found in Borges' 1931 essay called "Nuestras imposibilidades," from the first edition of his collection, Discusión. This essay, removed from later editions, criticizes what Borges believes to be certain unpleasant traits among the citizens of Buenos Aires and includes this condemnation of the cynical admiration for the "active" partner in sodomy among certain porteños: "En todos los países de la tierra, una indivisible reprobación recae sobre los dos ejecutores del inimaginable contacto. [...] No así entre el malevaje de Buenos Aires, que reclama una especie de veneración para el agente activo-porque lo embromó al compañero" (Discusión 16-17). There can be no doubt that Borges was openly homophobic when confronting the topic directly, but as is usually the case with his writing, things are more complicated than the surface might indicate. As this essay will demonstrate, despite the fact that Borges codifies the same-sex desire of a specific fictional character in unambiguously dreadful terms, it is my contention that that condemnation may be a clever way to mask his own unconscious identification with the character.

Part of the difficulty in locating a queer theme in Borges' writing is that there is nothing explicitly homosexual in any of Borges' stories. In societies which have vilified and demonized 
non-traditional sexualities - and within the Latin American context Argentina is particularly notable for its homophobic traditions, as Acevedo (220-239) and Jáuregui (157-193) demonstrate - the open, clear, explicit expression of homosexual desire is quite rare before the middle of the twentieth century. Before that time, only the most audacious and courageous writers dared to speak of the "unspeakable" or mention the "unmentionable." It is important to remember, as Lee Edelman illustrates, that the expression of same-sex desire has been classified throughout the centuries as the "love that dare not speak its name" or the "peccatum illud horribile, inter christianos non nominandum." In the Western tradition, then, homosexual desire has been considered so heinous, so infamous, so offensive that the mere mention of it can have damaging and noxious effects on society as a whole (5). In light of the judeo-christian history of virulent opposition to the simple designation of homosexuality, as well as of Borges' infamous aversion to sexuality itself (his characters almost without exception speak of sex as a "cosa horrible" as in "Emma Zunz" and in "La secta del fénix," sex is labeled ridiculous, vulgar, incredible, trivial, distressing and despicable), it certainly would be surprising to find an unveiled representation of homosexual themes or behavior in any of his fictions. In fact, in several stories Borges displays a veritable disgust with regard to sexual activity itself.

Unfortunately, there are those who demand "concrete evidence" of a homosexual element in a work of literature before anyone can even suggest that a character might be codified as gay. Such protestations demonstrate on the one hand, a naive ignorance of the Western cultural prohibitions on non-traditional sexualities, and, on the other, a limited view of the ways fictional art functions. Until very recently, both in life and in literature, heterosexuality could automatically be assumed, without evidence, as the orientation of all living beings. But as so much research has shown, that assumption has never been valid. Consequently, calls for explicit and concrete, yet strictly forbidden images of same-sex desire in certain works of literature suggest what Eve Kosofsky Sedgwick calls an "arrogant intent of maintaining ignorance" (51). 
Given Borges' open hostility to homosexuality (or any sexuality, for that matter), how can we say that there is anything gay in any of his texts? Despite the social injunction against the outright naming of homosexuality, same-sex desire has been insinuated for centuries by codification and camouflage. The code effectively conceals and obscures the homosexuality within the work, making it merely appear invisible or non-existent. One cannot, however, equate the appearance of nonexistence with nonexistence itself; the masking or coding of homosexuality does not translate into its absence. How, then, can a critic, as Edelman puts it, "see or recognize 'the homosexual' in order to bring 'homosexuality' into theoretical view? How, that is, can 'homosexuality' find its place in the discourse of contemporary criticism so that it will no longer be unmarked or invisible or perceptible only when tricked out in the most blatant thematic or referential drag?" (3-4). The answer must reside in the de-coding, the un-masking of the veiled expressions of same-sex desire and the subsequent revelation of hitherto unsuspected sexual variation in literary works, especially those works as loaded with masks, camouflages, and disguises as Borges' "La forma de la espada."

"La forma de la espada" is rare among Borges' stories: it has received decidedly mixed reviews and is, consequently, one of the texts least studied by critics. Of the negative appraisals of the story, probably the most unfavorable is Gene Bell-Villada's in which he calls "La forma de la espada" a "rather slight little tale" and goes so far as to say that it is "marred by its peevish and heavy-handed political judgments" (73). He points out that even Borges himself considered it a mere "trick story" (Burgin 145). But in contrast to these facile dismissals, most critics agree that it is a well written mystery story and that its surprise ending is playfully suggestive in its implications about the nature of human identity and the relationship between self and other.

The story's theme, according to most critics, is perfectly congruent with the traditional list of Borgesian themes established by scholars over the past thirty years: obsession with circularity, pantheism and the double. Donald McGrady, for example, analyzes the circularity inherent in the 
numerous clues with regard to the identity of the narrator. Helene Weldt, applying Barthes' principles of the five codes as explored in $S / Z$, also explores the textual circularity of the story and concludes that

la técnica que Borges emplea en ['La forma de la espada']... va más allá de un mero esparcimiento de 'pistas.' Su creación literaria se construye principalmente a través de esta red de alusiones e interconexiones sutiles que le obligan al lector a que abandone una sola lectura lineal, tradicional, a favor de las múltiples lecturas circulares (225-226).

Jaime Alazraki examines the question of identity and concludes that in this story, circularity and the "pantheistic notion that one man is all men implies the negation of individual identity, or more exactly, the reduction of all individuals to a general and supreme identity which contains all and at the same time makes all contained in each one. In the stories 'The Shape of the Sword' and 'Abenjacán the Bojari, Dead in His Labyrinth,' this notion functions as a narrative technique" (24). Like McGrady, George McMurray notes that the "most striking element" of the story is its surprise ending and then concurs with Alazraki that the "apparent fusion of opposites also serves to suggest the pantheistic theme that any man can be all men" (94) and that the "compression of time, which parallels the fusion of antithetical identities, reinforces the story's theme of pantheistic unity" (95).

Circularity, interconnectedness, fusion of opposite identities - all within a society of men. Circularity of men, interconnectedness of men, fusion of men. The critics all seem to agree on the basic abstract implications of the story, and once they place the story into the standard Borgesian categories, they stop. They stop before they get to the point where they would have to investigate what all this fusion of men mightreally suggest.

In the story "La forma de la espada," the main character, John Vincent Moon, acquires a coded sign that marks him, literally and figuratively, as queer. In the frame of the story, a man 
identified as "Borges" ("Forma" 139) must stay at the ranch of a man called "El Inglés de La Colorada" whose face bears a scar in the shape of a crescent moon beginning at the temple of one side of his head and extending to the cheek of the other side. Borges asks the man to tell how he got the scar. The man reveals his "secret:" he explains that he is really Irish, not English, and that the story begins in Ireland during the wars of independence. "El Inglés" states that during one of the conflicts, he saves the life of a particularly cowardly revolutionary, John Vincent Moon. Moon's terror makes him utterly useless for street fighting, and once superficially wounded, he stays in an old house which was "desmedrado y opaco y abundaba en perplejos corredores y en vanas antecámaras" ("Forma" 136-37). The two men remain in the house for nine days-"Esos nueve días, en mi recuerdo, forman un solo día, salvo el penúltimo" ("Forma" 138) - during which Moon spends the day studying the plans and papers of the revolutionary group while he recuperates. Returning to the house early one day, the narrator discovers Moon in telephone contact with the English, betraying his protector and friend. The narrator of the tale chases Moon through the labyrinthine corridors and passageways of the house and finally corners him. He delivers a slash with a scimitar across Moon's face, leaving a scar that will mark him forever as someone who is cowardly and treacherous - someone duplicitous. Moon collects his "dineros de Judas" and sets off for Brazil. The narrator finishes his story by declaring outright what the reader might already suspect: he himself is the betrayer, John Vincent Moon.

Some of the details of this story do not seem to make sense; there are a number of unexplained elements that, at first glance, are troubling. For example, although the courageous and experienced revolutionary saves Moon from certain death in the streets by taking his arm and pulling him to safety, Moon is only superficially wounded as a direct consequence of his own weakness and cowardice. Considering that the wound is not life-threatening, why do the two men hide out in an empty house rather than rejoining their comrades? Why does the courageous young revolutionary not only nurse the wound, but also insist on tending personally to Moon and 
keeping him there alone with him? Why do the two men remain together, side by side, night after night for nine days, in a strange old house, secluded and isolated from their companions? Could one or both of the men have engineered their seclusion in response to intense homoerotic desires?

I find that the answer to these questions lies in the highly codified figure of John Vincent Moon. He is described from the very beginning as a very queer sort of fellow-he seems to be many different things all at once. "El Inglés" states that Moon "era flaco y fofo a la vez; daba la incómoda impresión de ser invertebrado" ("Forma" 135). As McGrady indicates, the "contradictory condition of being at the same time 'flaco y fofo' suggests not a neutral Janus-like duality of temperament, but — because of the negative connotations of the two adjectivesdevious duplicity" (143). These gender-charged words used to describe Moon as skinny and soft, weak and spineless ("invertebrate") all indicate that Moon is not at all the brave and masculine warrior who courageously battles for the honor, either personal or national, that every "real" man is traditionally obliged to defend. Rather, the description of Moon specifically paints him as unmanly, effeminate and vulnerable. The image of Moon described here typifies the "misplaced femininity" with its resultant duplicity that heteropatriarchal societies attribute to any man who does not display typically "macho" qualities.

In addition to the physically feminine elements that characterize John Vincent Moon, a very important character trait plainly defines him as unmanly: his paralyzing fear and cowardice in the face of danger: "la pasión del miedo lo invalidaba." Not only is Moon rendered useless in the skirmish, but he also whimpers and cries: after he was wounded, "[él] prorrumpió en un débil sollozo" ("Forma" 136). Moon's humilliating inability to confront the hazards of fighting becomes even more apparent when the man who saved him suggests that they leave the house and join their comrades. After getting his gun he finds Moon "tendido en el sofá, con los ojos cerrados. Conjeturó que tenía fiebre; invocó un doloroso espasmo en el hombro" ("Forma" 137). 
Moon's need to pretend that he is too hurt to leave the house focuses attention on the fact that Moon is terrified by what is traditionally perceived of as an archetypally masculine activity, combat. This image of Moon, lying on his back in a traditionally passive, feminine posture, connects the characterization of Moon as both uncourageous as well as feminine, creating a link in the reader's mind between his unwillingness to fight and his weak, passive, unmanliness. Cowards are made "effeminate" and effeminate men are made cowardly because cultural norms have defined bravery as a masculine and heterosexual trait, while cowardice is fixed as feminine and homosexual.

It would be difficult to overstress the powerful resonance in the context of Argentine society of this portrait of Moon as an effeminate man who is frightened of combat. Such men are not only a danger to society because they might betray their own nation, but also because they have already betrayed their own gender: they are queers. In strongly heteropatriarchal cultures, behaviors that are considered non-conformist in terms of gender are equated instantaneously and automatically with sexual non-conformity: effeminate men are categorized as homosexuals by virtue of the lack of those macho features specifically prescribed by the culture. In fact, as David Buchbinder and Barbara Milech affirm, "[e]ffeminacy in the male becomes for the normative heterosexual culture, the sign of homosexuality itself, of deviance from the masculine, heterosexual norm, of ab-'normality"' (71). In Hispanic cultures, too, as Lillian Manzor-Coats states, the designation of a man as "homosexual" is determined primarily by his gender identity:

The category homosexual is not necessarily occupied by the one who is inolved in same-sex erotic practices, but by the one who deviates from the gender constructs. In other words, in most societies in Latin America a man who engages in homosexual activity with other men is considered to be queer, maricón, only if and when he does not play his role as macho - that is, when he assumes the sexual and social role of the passive, the open, the weak; when he assumes the position and plays the role of woman. As long as he plays his active role as macho 
properly, the gender of his sexual partner is inconsequential, and he remains indistinguishable from the rest of the male population. (xxi)

The distinctly Hispanic construction of homosexual identity helps provide a culturally specific context for assessing the implications of Borges' characterization of Moon. In the text, Moon's queerness resides primarily in his gender non-conformity which metonymically proclaims his sexual "deviation."

The issue of cowardice also has specifically Argentine reverberations. Zelmar Acevedo, in his study on homosexuality, for example, discusses the intimate link between Argentina's traditional glorification of military values and its crushing heterosexism. The numerous military dictatorships throughout Argentina's history could be considered both an underlying cause as well as an effect of socially reinforced homophobia and almost without exception, every military government in Argentina since the turn of the twentieth century has launched a carefully orchestrated and public crack-down on homosexuals. This homophobic project is exemplified by an article, "Acabar con los homosexuales," which appeared in the early 1970s in a right-wing magazine called El Caudillo. As Acevedo notes, the magazine's director was José López Rega, M. Estela Martínez de Perón's minister of Social Welfare. The article affirms that

...los maricones deben ser erradicados de nuestra sociedad./ Deben prohibirse las exhibiciones de cine, televisión o teatro que difundan esa perversión al pueblo. El enemigo quiere y busca un país vencido./ A los que ya son proponemos que se los interne en campos de reeducación y trabajo, para que de esa manera cumplan con dos objetivos: estar lejos de la ciudad y compensar a la Nación — trabajando-la pérdida de un hombre útil./ Hay que acabar con los homosexuales./ Tenemos que crear Brigadas Callejeras que salgan a recorrer los barrios de las ciudades para que den caza a estos sujetos vestidos como mujeres, hablando como mujeres, pensando como mujeres. (216)

These opinions express with great clarity the fascist cultural beliefs that 1) homosexual men are dangerous because they weaken a nation, making it vulnerable to its enemies, 2) homosexual 
men are useless and represent the loss or waste of a "real man," and 3) the femininity of homosexual men makes them not only appear womanly, but even causes them tothink like women. It is this feminine thinking that is so perverse and menacing.

In Argentine culture, as in the work of Borges, the overtly expressed admiration and even veneration of the concept of masculine power is manifested through military authority. ${ }^{3}$ As a result, Borges, in this story, makes the link between a threat to masculine gender and the threat to military strength by collapsing the percieved menace in the figure of an effeminate traitor who betrays the masculine fighter. As a soldier in the fight for Irish independence, Moon actually becomes more dangerous than the English enemy because he represents the "subversive" element that threatens other soldiers from within their own camp.

Moon is incapable of any type of direct action that characterizes his brave protector and it is precisely this passivity that is accentuated by a description of his thoroughly intellectual and abstract approach to war: "[m]i compañero me esperaba en el primer piso: la herida no le permitía descender a la planta baja. Lo rememoro con algún libro de estrategia en la mano..." ("Forma" 138). The contrast between the two men is made explicit: the admirable, honorable, manly aspects of the hero find their opposition in the despicable, disgraceful and feminine elements of the traitor. As a result, there can be no mistake about the description of Moon: he appears to be the very picture of the stereotypical weak, soft, and passive "sissy." The result of such unmistakable feminine characteristics present in a male are not only disturbing ("incómoda impresión"), but also, as the ending reveals, dangerous.

To reinforce and emphasize Moon's femininity and passivity as well as his inconsistency, Borges has selected a curiously symbolic surname. As Juan-Eduardo Cirlot indicates, the relationship between the moon, feminine sexuality and changeability is ancient and runs across a variety of cultures: "[e]l hombre percibió, de antiguo, la relación existente entre la luna y las mareas; la conexión más extraña aún entre el ciclo lunar y el ciclo fisiológico de la mujer" (283); 
"[p]or su carácter pasivo, al recibir la luz solar, es asimilada al principio del dos y de la pasividad o lo femenino" (284). As a scholar on symbolism and metaphor in both the Easter and Western traditions, and as an author who was playful in his use of symbolic names, it is probable that Borges chose the name "Moon" for its specific symbolic connotations. Certainly Borges was fully aware of the link between the feminine and the lunar. Julio Woscoboinik, for example, correctly indicates that "[n]o podemos dejar de mencionar que Luna es una metáfora muy frecuente en Borges para decir acerca de la mujer" (154).

In addition to the feminine qualities of the moon, Cirlot indicates another very important symbolic quality of moon: it constantly varies and transforms itself, yet it remains a single entity. "[P]or encima de todo, es el ser que no permanece siempre idéntico a sí mismo, sino que experimenta modificaciones 'dolorosas' en forma de círculo clara y continuamente observable" (283). The phases of the moon from new to crescent to full, all characterize the everchanging identity of John Vincent Moon. The fact that Moon appears to embody a multiplicity of seemingly opposing attributes is underscored, again, by his name. He may appear to be many different things, but he is, despite all the disguises, one person. Woscoboinik perceptively points out that "...Borges hace referencia a la palabra LUNA y la compara con MOON, su designación en inglés. Le place MOON 'porque obliga la voz a demorarse'. Palabras sugerentes: a Borges no le pasó inadvertido, que luna tiene involucrada una y que moon, fonéticamente (mun), también encierra $u n^{\prime \prime}(154)$. John Vincent Moon is the physical embodiment of the unification of opposites, the conjunction of paradoxical dualities: feminine and masculine; unity and duality; love and betrayal.

The emphasis placed on Moon's feminine inconstancy serves to make Moon's treachery appear more understandable and consistent with his character. But this linking of femininity within the confines of a male body with the heinous crime of betrayal also serves to reinforce and strengthen the stereotypes that Western heteropatriarchal societies have utilized in order to 
demonize homosexuals. As a result, Borges' characterization of John Vincent Moon amplifies the infamy of gay men by conjoining same-sex desire with deceitfulness. Since "El Inglés" never explains the reasons underlying Moon's decision to betray his comrade, the reader is left with the impression that the action was unmotivated, and therefore, simply to be expected in a man like Moon: Moon exposes his inherently treacherous nature when he repays his protector and savior with disloyalty for what seems like no good reason. As will be shown later in this study, money alone does not and cannot account for the betrayal: there are no textual indications that would suggest that Moon was in desperate need of money, or was particularly greedy. In fact, the references to Moon's marxist political affiliation effectively negate the love of money as a motivating force in his actions.

The narrator's depiction of Moon (i.e. himself) in homophobic terms taps into the commonly held belief that homosexuals are condemned to commit ignoble actions: "[g]ays are viewed first and foremost simply as morally lesser beings, like animals, children, or dirt, not as failed full moral agents. [...] Such acts as gays are thought to perform—whether sexual, gestural, or social—are viewed socially as the expected or even necessary efflorescence of gays' lesser moral state, of their status as lesser beings..." (Mohr 245-46).

John Vincent Moon lacks the nobility of character embodied in the masculine hero figure: courage and bravery, physical strength, constant devotion to the ideal. Although Moon's betrayal of the young republican may be understood as the vile, but inevitable, action directly resulting from his status as a spiritually degenerate pervert, the critical motivation underlying his action becomes clear at the moment when he is explicitly connected to the archetype of the treacherous and envious traitor: Judas. Moon arranges the betrayal of his companion by informing the British soldiers that they can arrest him as he crosses through a garden, and then, after the horrible deed is done, Moon "[c]obró los dineros de Judas y huyó al Brasil" ("Forma" 139). The Judas 
archetype is a very powerful one and its potency lies in the fact that, as Carl Jung puts it, "...envy does not let mankind sleep in peace" (31).

Envy is one of the central and defining features of Moon's character: a weak and feminine man feels an unbridled envy for the attractive, desirable qualities of a friend and this envy leads to murder. In the process, the murderer is permanently marked. The homosexual, a freakish woman imprisoned in a male body, must possess the worst imaginable "feminine" impulses. At this point, it might help to recall that since Borges' father was a professor of psychology, it is therefore possible, if not very likely, that Borges, due to his remarkably wide reading interests, language abilities, and access to his father's exceptional library, had come across the work of Karl Heinrich Ulrichs and his formulation of sexual "inversion" as a "woman's soul trapped in a man's body" ("anima muliebris virili corpore inclusa") and that it was this and other Victorian concepts that formed his understanding of same-sex desire. In his study of the Argentine theorization of homosexuality at the turn of the century, Daniel Bao notes that the traditional negative stereotypes of women were, in fact, transferred over to "inverts" because of their supposed female "essence." Bao quotes a particularly revealing text from 1908 by the lawyer and criminologist, Eusebio Gómez, which states that

[a]l rasgo que acabamos de indicar en los invertidos, la venalidad, ó más bien dicho, el parasitismo, únese su carácter caprichoso, sus envidias, la ruindad de todos sus procederes, su deseo de venganza, y sus rencores ilimitados. Tarnowski dice que reunen en sí todos los defectos de las mujeres sin tener ninguna de sus cualidades, careciendo, además de las condiciones que hacen amable el carácter viril.

Gómez further notes that inverts "[s]on celosos y esta pasión los lleva hasta el crimen. Un sensacional proceso recientemente debatido ante la justicia militar, acaba de dar la prueba al respecto" (199; emphasis added). It is fascinating to find that a scandal within the Argentine 
military at the turn of the century caused debate on the question of "inverts" among the soldiers. Fascinating, too, is the fact that in 1942, only two years before Borges' story appeared, the Argentine military again suffered another devastating scandal involving cadets from the Colegio Militar. As Acevedo remarks, the events stunned a military so proud of its martial heritage: "[p]recisamente en momentos en que las FF.AA. daban forma a sus ambiciones totalitarias y una perorata de conceptos como virilidad y honor llenaban todas las bocas, la relación entre cadetes y homosexuales, en la que no participaba ninguna violencia, los desnudaba en sus límites y en sus contradicciones; y si es verdad que este affaire los tomó por sorpresa, de ahí en más combaritían la 'inmoralidad' adelantándose a los hechos" (229). This prevailing cultural conceptualization of homosexuality may elucidate Borges' attitude that homosexuals can't be trusted; you can't turn your back on them; they are, by nature, treacherous and their fiendish kisses mark the victims of their betrayal.

But Borges goes even further. Invoking two Biblical models, one from the Old Testament and the other from the New, Borges combines the envy of Cain and his killing of Abel (Gen. 4:3-8) with the envy of Judas that leads him to mark Jesus for death with a kiss (Matt. 27:18, Mark 15:10) and concentrates their attributes in the person of John Vincent Moon. In this way, Moon becomes a contemporary incarnation of a long series of deadly betrayers. Moon's heritage, then, is that of the primordial fratricide as well as the assassin of God.

By linking the image of Cain/Judas with the image of a cowardly, envious, feminized man, Borges makes the case that homosexuals pose a danger and a threat to the security and safety of us all. In order to protect us from their envy, jealousy, duplicity, disloyalty, and deceitfulness, homosexuals need to be identified and labeled as quickly and easily as possible. So Borges returns to the symbolism of Cain and, like the Old Testament God, he marks his character with a sign. This marking of Moon follows a Western tradition of attempting to find a visible, physical difference in homosexuals so that their particularly frightening menace would become 
obvious to all and could then be neutralized. As a consequence of the need to locate and label homosexuals, scientists in the nineteenth century came to theorize that gays were indeed physically different in appearance - their bodies bore a mark, a sign, a stigma that could be recognized instantly. Indeed, Michel Foucault asserts that it is this marking that, in effect, provides homosexuals with a distinct identity and selfhood:

The nineteenth-century homosexual became a personage, a past, a case history, and a childhood, in addition to being a type of life, a life form, and a morphology, with an indiscreet anatomy and possibly a mysterious physiology. Nothing that went into his total composition was unaffected by his sexuality. It was everywhere present in him: at the root of all his actions because it was their insidious and indefinitely active principle; written immodestly on his face and body because it was a secret that always gave itself away. It was consubstantial with him, less a habitual sin than as a singular nature. (43; emphasis added)

Edelman further stresses the "textuality" and "readability" of the queer body insofar as "homosexuals themselves have been seen as producing—and, by some medical 'experts,' as being produced by — bodies that bore a distinct, and therefore legible, anatomical code. [...] Homosexuals, in other words, were not only conceptualized in terms of a radically potent, if negatively charged, relation to signifying practices, but also subjected to a cultural imperative that viewed them as inherently textual — as bodies that might well bear a 'hallmark' that could, and must, be read" (5-6). Given this social context, it becomes clear why the young hero, once he discovers Moon's act of betrayal, does not use his gun and simply shoot Moon dead, but rather chases him through a dark and somewhat unfamiliar house with, of all things, a scimitar: Moon's desires for men and his betrayal of them must be made visible to society in such a way that he is instantly identifiable. John Vincent Moon, with the crescent moon-shaped scar running across his face, forever bears the mark of the man who has desired and deceived another man and, lest he escape imperceptibly to love and betray again, he is permanently branded by an object (a sword) 
that symbolizes what he most desires (the phallus). The proscribed desire of one man for another that comes from a presumed inferior moral status is given tangible form: "[i]mperfecciones morales, sufrimientos (¿son lo mismo?) son, pues, simbolizados por heridas y por cicatrices de hierro y fuego" (Cirlot 127; emphasis added).

As Balderston has noted ("Mark"), this is not, of course, the only instance in which a man marked with a facial scar appears in Borges' work. One of the most unusual and perhaps unfamiliar is a line drawing made by Borges himself which, as Woscoboinik indicates, was published in the magazine Valoraciones de La Plata in August of 1926. The drawing is called "Compadrito de la edad de oro" and in it there is a figure of one of the young toughs that so fascinated and disgusted Borges. Woscoboinik interprets the drawing in this way:

Mientras el rostro aindiado muestra una expresión dura, desafiante, prepotente, de mirada atenta y provocativa, bigotes marcados y una clara cicatriz, el cuerpo insinúa elementos de inseguridad y ambigüedad sexual: cortada la figura por encima de las rodillas, las caderas son de formas redondeadas, femeninas. [...] Pero lo más llamativo, es la cicatriz en el rostro. Este trazo de dos líneas cruzadas, se repite en el cuello, más claramente en axilas, hombro derecho, en lo que serían los bolsillos del saco del pantalón y en la zona genital. (120)

In this drawing Borges clearly demonstrates that although a man may appear to be tough, courageous and manly on the outside, there seems to be a subtle femininity that belies the outward appearance. The outward image projected by the "compadrito" would appear to be the ultimate in courage, honor and masculinity, but on closer inspection the figure is marked with several obvious feminine characteristics and with a scar on the face to inform the world that he is not what he appears to be. The danger of the "compadrito," like the danger of John Vincent Moon (in his "El Inglés" persona), is precisely the fact that a man can appear to be manly on the outside, but he can be womanly on the inside and that for Borges, the unreliable nature of this 
"complexio oppositorum" is monstrous indeed: it combines attractive virile qualities such as activity, bravery, and heroism with such despicable feminine qualities as passivity, cowardice, and treachery.

The ending of the story, the result of Moon's betrayal, is curious. Following the Biblical allusions, Borges can select from two choices: Moon can either give back the money and hang himself out of shame and guilt like Judas (Matt. 27:3-5) or he can become a fugitive like Cain (Gen. 4:12-14) and leave his homeland. In an odd move, Borges chooses a combination of the two: Moon flees Ireland, runs off to South America, and buys a ranch with the "Judas money" he got from the English. But because of the permanent scar on his face to inform others of his nature, he is forced into making a spectacular decision: he can either continue to live as the cowardly and "feminine" John Vincent Moon, wearing the mark of shame and being the object of derision, or he can convert himself into what was his most fervent desire. With the death of his comrade, the man he adored but had to betray, he is able to come into possession of him by literally becoming him. The copula of the two men is complete when Moon's desire for the young hero becomes so intense and so powerful that the desire is transformed ultimately into identity. The soft and spineless John Vincent Moon disappears; the coward actually converts himself into the courageous and manly hero. Moon, in effect, acquires the identity of his comrade and now wears the mask of a hero. In this way, the soft, youthful sissy-boy, despite being marked with the stigma of his desire, continues to fool people, continues to keep his queerness a secret by putting on the drag of the hyper-masculine rancher and living within the exclusively male environment of a ranch.

The treacherous, timid and feminine John Vincent Moon, in a remarkable reversal of imagery, becomes respected and feared: "[d]icen que era severo hasta la crueldad, pero escrupulosamente justo" ("Forma" 133). By betraying his friend, Moon (as "El Inglés") ultimately earns the respect of others; by acting fearfully, Moon is eventually feared by others. 
But those who respect and fear him do not know the ugly secret of "El Inglés": he is a mere imitation, a simulacrum, a fake. What we find in Borges, then, is a conflict between the truly courageous hero and those who, out of a desire to be (like) them, possess them, have them, usurp their position of honor by putting on the mask of masculinity and imitating them. In Borges, the portrayal of the hero can be quite contradictory. Lanin Gyurko has noted: "[t]he cult of the Macho, of the man who affirms his virility through a violent public display of courage and prowess, is viewed ambivalently by Borges in his short stories. [...] The caricaturing of the [machismo] cult and the debunking of the hero are seen in many of Borges' stories, which depict persons who are publicly accepted as champions but who are really braggarts, incompetents, cowards and liars" (128). Perhaps part of Borges' contempt for certain macho heroes comes from his suspicion that in addition to being cowards and liars, beneath the mask of the tough guy there may also be hiding a cowardly queer. In a 1977 interview with Milton Fornaro, for example, Borges draws a very clear distinction between the brave fighter, worthy of admiration, and the sexually questionable cowards and "rufianes":

Del cuchillero, lo que yo admiro es la idea de un individuo que, como decía Carriego, es cultor del coraje, que tiene el culto del coraje. [...] El cuchillero es un hombre desinteresado. El cuchillero despreciaba al rufián. El rufián era una persona muy despreciada entre el malevaje, y el cobarde también. El rufián sí, porque el rufián es una persona que vive de las mujeres, era casi peor que ser maricón. No se le veía como nada admirable. (113)

Like his creation, Moon, Borges admires the courageous macho man. In fact, Moon and Borges have a great deal in common. Considering the relentlessly negative characterization of Moon, it is odd that Borges would make the character so much like himself. For example, the desire for the virile qualities that led Moon to adopt the identity of his dead companion 
represents the very same yearning that Borges expressed so often with respect to his own heroic ancestors. Borges spoke frequently and passionately about the esteem and regard he held for his noble and courageous forefathers, while in contrast to them, he speaks of himself in these terms:

I felt ashamed, quite early, to be a bookish kind of person and not a man of action. Throughout my boyhood, I thought that to be loved would have amounted to an injustice. I did not feel I deserved any particular love, and I remember my birthdays filled me with shame, because everyone heaped gifts on me when I thought that I had done nothing to deserve them-that $I$ was a kind of fake. ("Autobiographical Essay" 208-209; emphasis added)

The self-deprecating phrases he uses for himself, the fact that he did not feel worthy of love because of his lack of manly activity, and his believing himself to be a "fake" are all elements suggesting a close affinity between Moon and Borges. Although by nature neither Moon nor Borges participate in virile pursuits, they both admire and delight in them and feel ashamed for that lack of "masculinity" in themselves. It is clear that Borges, like Moon, is envious of those men who embody masculine virtues. Furthermore, both of them share a pronounced intellectual bent. As "El Inglés" says of Moon, "[p]ara mostrar que le era indiferente ser un cobarde físico, magnificaba su soberbia mental" ("Forma" 138). In the end, it appears that the figure of John Vincent Moon represents those characteristics of Borges that he most despised in himself: the cowardice, the passivity, the envy_all those despicable feminine attributes that may have caused Borges to question his own sexuality.

Given the cultural context in which Borges grew up, it is unfortunate, although not surprising, that he would link same-sex desire with fear and loathing. So just when Moon might have gotten away with his monstrous secret, he is confronted by the character Borges on his ranch and, on the specific condition that Borges "no mitigar ningún oprobio, ninguna circunstancia de infamia" ("Forma" 134-35), Moon both explains the origin and cause of the scar, and in the process "outs" himself to the reader by revealing his true identity as a coward, a 
betrayer, and a homosexual. Moon's confession of his "secreto" reinforces the misconception that homoerotic desire cannot have positive results and that it ultimately leads to tragedy and death. He is living proof that gays must be immediately identifiable. The mark or brand will serve to keep society safe from the dangers that queers present if they are permitted to roam freely, to "pass" undetected among us. John Vincent Moon, the Judas who kisses and then betrays the men he most admires and desires, disfigured forever, serves as the example of what horrors same-sex desires bring. Moon's final words to Borges, the final words of the story, summarize the lesson that society has been pounding into homosexuals' heads for centuries: now that you know who and what I am, "[a]hora desprécieme" ("Forma" 140). 


\section{NOTES}

${ }^{1}$ The use of the word "queer" remains quite controversial. For some, the original meaning of "strange" or "abnormal" used in a harmful and aggressive way against homosexuals still retains the painful stigma of an insult. For others, including myself, the appropriation of the word by those who had been harmed by it has neutralized its offensive value and has provided a convenient way of expressing a wide array of non-heterosexual sexualities as well as a critical stance that opposes assumptions of monolithic sexual identity.

2Jean Franco, in her excellent 1981 study, points out that many of Borges' stories are based on his obsession with the themes of betrayal and cowardice and that "[t]reachery is thus the rule of human interaction and entropy is the most powerful law of Borges's world; solidarity, on the other hand, becomes an absurd and idealist illusion" (74).

${ }^{3}$ Borges' conservative political ideology and esteem for Argentine military heritage are well known. See Benedetti and Orgambide for rather negative assessments of Borges' position. It must be said, however, that at the end of his life, when confronted with the horrors of the "Dirty War" conducted by the Argentine military, Borges repudiated his earlier views. 


\section{WORKS CITED}

Acevedo, Zelmar. Homosexualidad: Hacia la destrucción de los mitos. Buenos Aires: Del Ser, 1985.

Agheana, Ion T. Reasoned Thematic Dictionary of the Prose of Jorge Luis Borges. Hanover [NH]: Ediciones del Norte, 1990.

Alazraki, Jaime. Jorge Luis Borges. Columbia Essays on Modern Writers 57. New York: Columbia UP, 1971.

Altamiranda, Daniel. "Jorge Luis Borges (Argentina; 1899-1986)." Latin American Writers on Gay and Lesbian Themes: A Bio-Critical Sourcebook. Ed. David William Foster. Westport: Greenwood P, 1994. 72-83.

Balderston, Daniel. "The Fecal Dialectic: Homosexual Panic and the Origin of Writing in Borges.” ¿Entiendes? Queer Readings, Hispanic Writings. Eds. Emilie L. Bergmann and Paul Julian Smith. Durham: Duke UP, 1995. 29-45.

---. "The Mark of the Knife: Scars as Sign in Borges." The Modern Language Review 83.1 (1988): 67-75.

Bao, Daniel. "Invertidos Sexuales, Tortilleras, and Maricas Machos: The Construction of Homosexuality in Buenos Aires, Argentina, 1900-1950." Journal of Homosexuality 24.3/4 (1993): 183-219.

Bell-Villada, Gene H. Borges and His Fiction: A Guide to His Mind and Art. Chapel Hill: U of North Carolina P, 1981.

Benedetti, Mario. "Borges o el fascismo ingenioso." In his El recurso del supremo patriarca. México: Nueva Imagen, 1979. 93-99. 
Borges, Jorge Luis. "An Autobiographical Essay." In The Aleph and Other Stories 1933-1969.

New York: E. P. Dutton, 1970. 201-260.

---. Discusión. 1st ed. Buenos Aires: M. Gleizer, 1932.

---. Ficciones. Madrid: Alianza, 1982.

Buchbinder, David and Barbara H. Milech. "Construction Site: The Male Homosexual Subject in Narrative." Works and Days: Essays in the Socio-Historical Dimension of Literature and the Arts 9.18 (Fall 1991): 67-87.

Burgin, Richard. Conversations with Jorge Luis Borges. New York: Avon Books, 1970.

Cirlot, Juan-Eduardo. Diccionario de símbolos. 3rd edition. Barcelona: Editorial Labor, 1979.

Edelman, Lee. Homographesis: Essays in Gay Literary and Cultural Theory. New York: Routledge, 1994.

Fornaro, Milton. "El otro, el mismo Borges." Texto Crítico 3.8 (1977): 108-16.

Foucault, Michel. The History of Sexuality. Volume I: An Introduction. Trans. Robert Hurley.

New York: Vintage, 1980.

Franco, Jean. "The Utopia of a Tired Man: Jorge Luis Borges." Social Text 4 (Fall 1981): 52-78.

Gyurko, Lanin A. "Borges and the Machismo Cult." Revista Hispánica Moderna 36.3 (1970-71): 128-45.

Jáuregui, Carlos Luis. La homosexualidad en la Argentina. Buenos Aires: Ediciones Tarso, 1978.

Jung, C. G. Symbols of Transformation: An Analysis of the Prelude to a Case of Schizophrenia. Vol. 5 of The Collected Works of C. G. Jung. Trans. R. F. C. Hull. 2nd ed. Bollingen Series XX. Princeton: Princeton UP, 1967.

Lancaster, Roger N. "Subject Honor and Object Shame: The Construction of Male Homosexuality and Stigma in Nicaragua." Ethnology 27.2 (1987): 111-125.

Magnarelli, Sharon. "Literature and Desire: Women in the Fiction of Jorge Luis Borges." Revista/Review Interamericana 13.1-4 (1983): 138-149. 
Manzor-Coats, Lillian. "Introduction." Latin American Writers on Gay and Lesbian Themes: A Bio-Critical Sourcebook. Ed. David William Foster. Westport: Greenwood P, 1994. xvxxxvi.

McGrady, Donald. "Prefiguration, Narrative Transgression and Eternal Return in Borges' 'La forma de la espada'." Revista Canadiense de Estudios Hispánicos 12.1 (1987): 141-49.

McMurray, George R. Jorge Luis Borges. New York: Frederick Ungar, 1980.

Mohr, Richard D. Gay Ideas: Outing and Other Controversies. Boston: Beacon P, 1992.

Molloy, Silvia. Signs of Borges. Trans. Oscar Montero. Durham: Duke UP, 1994.

Orgambide, Pedro. Borges y su pensamiento político. México: Comité de Solidaridad con el Pueblo Argentino, 1978.

Rodríguez Monegal, Emir. Jorge Luis Borges: A Literary Biography. New York: Paragon House, 1988.

Salessi, Jorge. "The Argentine Dissemination of Homosexuality, 1890-1914." Journal of the History of Sexuality 4.3 (1994): 337-368.

Sedgwick, Eve Kosofsky. Epistemology of the Closet. Berkeley: U of California P, 1990.

Weldt, Helene. "La forma del relato borgiano: Las lecturas circulares de 'La forma de la espada'." Symposium 45.3 (1991): 218-227.

Woscoboinik, Julio. El secreto de Borges. Indagación psicoanalítica de su obra. Buenos Aires: Editorial Trieb, 1988. 